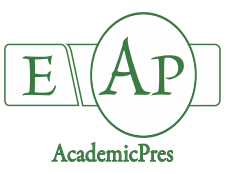

Palacio-Márquez A et al. (2021)

Notulae Botanicae Horti Agrobotanici Cluj-Napoca

Volume 49, Issue 1, Article number 12123

DOI: $10.15835 /$ nbha 49112123

Research Article

\title{
Biofortification potential in common bean (Phaseolus vulgaris L.): bioactive compounds, antioxidant capacity and physicochemical properties of 155 varieties grown in México
}

\author{
Alejandro PALACIO-MÁRQUEZ ${ }^{1}$, Damaris OJEDA-BARRIOS ${ }^{1}$, Jorge \\ JIMÉNEZ-CASTRO ${ }^{1}$, Pablo PRECIADO-RANGEL ${ }^{2}$, Ofelia A. \\ HERNÁNDEZ-RODRÍGUEZ ${ }^{1}$, Esteban SÁNCHEZ ${ }^{3 *}$
} ${ }^{1}$ Universidad Autónoma de Chihuahua, Facultad de Ciencias Agrotecnológicas, V. Carranza y Escorza S/N. Col. Centro.31000
Chihuahua, Chihuahua, México; alexmarquezmj8@gmail.com; dojeda@uach.mx; jajimenez@uach.mx; aernande@uach.mx
2Instituto Tecnológico Nacional de México - Instituto Tecnológico de Torreón (ITT),27170 Torreón, Coahuila,
México; ppreciador@yahoo.com.mx
${ }^{3}$ Centro de Investigación en Alimentación y Desarrollo A. C., Avenida Cuarta Sur 3820 Fraccionamiento Vencedores del Desierto.
33089Delicias, Chihuahua, México; esteban@ciad.mx (*orresponding author)

\begin{abstract}
Common bean has been classified as an almost perfect food due to its high content of fiber, protein and bioactive compounds and its high antioxidant capacity, which has been attributed to having prevent diabetes, oxidative stress, bowel inflammation and cardiovascular diseases. The objective of this research work was to characterize the physicochemical properties and bioactive compounds of 155 varieties of common bean (Phaseolus vulgaris L.) produced in Mexico with potential to be biofortified. The contents of protein, fiber, fat, carbohydrates and energy were analyzed by the methods established by the AOAC, in addition the antioxidant capacity (DPPH), the content of total phenols, flavonoids, anthocyanins and phytic acid were obtained. Cluster, correlation, and principal component analysis were conducted. A total of 14 outstanding varieties was identified, where four varieties stood out about phenol and flavonoid content. A second group comprised by 10 varieties had high protein and anthocyanin levels and showed the second highest content of phenols and flavonoids. The diversity of beans obtained in outstanding varieties provides options for biofortification programs based on the consumption or place of origin of each variety.
\end{abstract}

Keywords: biodiversity; biofortification; nutritional quality; Phaseolus sp.

\section{Introduction}

At present, changes in demand of food and trends to consume products containing beneficial compounds for health, in addition to a promotion towards plant based products, has forced the industry to find new dietary attributes in its products, so they may have the capacity of attracting new market preferences without neglecting the nutritional quality of the crops, being one of the most important parameters that must

Received: 20 Oct 2020. Received in revised form: 21 Dec 2020. Accepted: 22 Mar 2021. Published online: 24 Mar 2021.

From Volume 49, Issue 1, 2021, Notulae Botanicae Horti Agrobotanici Cluj-Napoca journal will use article numbers in place of the traditional method of continuous pagination through the volume. The journal will continue to appear quarterly, as before, with four annual numbers. 
be taken into account when talking about food, since they determine their functionality in the diet (SidaArreola et al., 2015; Gutiérrez, 2012).

Legumes, such as beans, lentils or chickpeas, have been considered as staple foods, due to their nutritional quality and because they have shown the ability to improve human health. Within this group, beans are the most consumed legume in the world, having an average per capita of $6.6 \mathrm{Kg}$. Around 150 species of beans are known, of which approximately 70 varieties have their center of origin in Mexico with a great variety of sizes and colors (FIRA, 2016; Silva-Cristobal et al., 2010).

Among the nutritional properties of beans, one of the most notable is its high protein content and to a lesser extent its contribution of carbohydrates, vitamins and a high contribution of fibers and minerals such as calcium, iron and zinc, beans are also rich in antioxidants due to its high phenol content (Korus et al., 2007; Ulloa et al., 2011). The protein content in beans ranges between $15 \%$ and $30 \%$, a $90 \mathrm{~g}$ portion of beans provides from 7 to $8 \mathrm{~g}$ of protein, which constitutes $15 \%$ of the recommended daily intake, they also have enough content to meet the needs daily basic amino acids lysine (6.4-7.6 g. $100 \mathrm{~g}^{-1}$ of protein) and phenylalanine plus tyrosine (5.3-8.2 g. $100 \mathrm{~g}^{-1}$ of protein) (Mederos, 2006; Suárez-Martínez et al., 2016). Beans are also a good source of fiber with values that vary from $14 \mathrm{~g}$ to $19 \mathrm{~g}$ per $100 \mathrm{~g}$ of raw food, of which it can reach $50 \%$ soluble fiber, which has been related to a reduction in cholesterol levels (Messina, 2014).

The common bean has been classified as an almost perfect food, due to its high content of fiber, protein, its high antioxidant capacity and the large number of bioactive compounds it has, to which qualities have been attributed in the prevention of diseases such as diabetes, oxidative stress, intestinal inflammation and cardiovascular diseases (Xu and Chang, 2009; Câmara et al., 2013). These effects are related to the high antioxidant capacity, granted by high concentrations of phenols, flavonoids and to a lesser extent anthocyanin and phytic acid, which in turn generate antimutagenic and antigenotoxic effects (Akond et al., 2011 ${ }^{1}$ ). However, Suárez-Martínez et al. (2016), suggest that it is necessary to make efforts to increase bean consumption, making the population aware of the benefits attributed to it. Based on the above, the objective of this research work was to characterize the physicochemical properties and bioactive compounds of 155 varieties of beans produced in Mexico with potential to be biofortified.

\section{Materials and Methods}

\section{Selection of material}

One hundred and fifty-three varieties of beans (Phaseolus vulgaris L.) were used, representative of all Mexico, based on the consumption preference of the States of Chihuahua, Durango, Zacatecas, Sinaloa, Tabasco, Yucatán, Oaxaca, Veracruz, Puebla, Jalisco, Morelos, Guanajuato, Michoacán and State of Mexico, in addition to two more samples from Cuba selected for their nutritional quality.

\section{Reagents used}

The following reagents were used: potassium sulphate (99.4\%), sulfuric acid (97\%), sodium hydroxide (97\%), boric acid (100\%), hydrochloric acid $(38 \%)$, petroleum ether $\left(35-60{ }^{\circ} \mathrm{C}\right)$, isoamyl alcohol $(99.7 \%)$, methanol (99.97\%), sodium carbonate (100\%), potassium chloride (99\%) and sodium acetate (99.3\%), all of them obtained from JT Baker (USA), DPPH, sodium nitrite (99\%), Folin-Ciocalteau, aluminum chloride (99\%) and catechin (98\%) acquired from Sigma-Aldrich (USA) and gallic acid (99.5\%) from CTR (MEX) were used too.

\section{Assessed variables}

Once the bean materials were obtained, they were cleaned, selected and milled to perform the analysis of physicochemical properties and bioactive compounds, which were determined in accordance with the 
Association of Official Analytical Chemists (AOAC 2000) and in accordance with the provisions of the Official Standards Current Mexicans. The parameters evaluated were the following:

\section{Determination of physicochemical properties}

$\underline{\text { Protein }}$

Protein determination was performed using the Kjeldahl method of the Association of Official Analytical Chemists (AOAC, 2000). $1 \mathrm{~g}$ of homogenized sample was weighed into a Kjeldahl digestion flask, 3 boiling beads, $10 \mathrm{~g}$ of potassium sulfate and $20 \mathrm{ml}$ of concentrated sulfuric acid were added for digestion. When the mixture became clear, it was allowed to cool, and $200 \mathrm{ml}$ of tri-distilled water was added. It was connected to the still while adding $100 \mathrm{ml}$ of $30 \%$ sodium hydroxide, distilled and at least $150 \mathrm{ml}$ was collected in a flask containing $50 \mathrm{ml}$ of $3 \%$ boric acid and titrated with $0.1 \mathrm{~N}$ hydrochloric acid. The results obtained were multiplied by the factor 6.25 and expressed as a percentage.

\section{Total fat}

The determination of the fat of the bean samples was carried out using the Goldfish method (AOAC, 2000). Goldfish flasks were prepared by oven drying to constant weight. The LABCONCO equipment was assembled and the sample was placed inside filter papers and covered with cotton and introduced into the equipment. Solvent (petroleum ether) was added and refluxed for 2.5 hours. After the extraction was complete, the solvent was recovered by distillation, leaving only the fat in the flask. Finally, the flask with the residue was weighed and the fat percentage was determined according to the Mexican Standard NMX-F-427-1982 published in the official gazette of the federation by the government secretary.

\section{Crude fiber}

Crude fiber was determined by the Mexican Standard NMX-F-90-S-1978 published in the official gazette of the federation by the government secretary. From the sample that was previously degreased. The weight of the sample was recorded and transferred to the fiber cups, then $200 \mathrm{ml}$ of $1.25 \%$ sulfuric acid with 1 $\mathrm{ml}$ of isoamyl alcohol as defoamer was added to each beaker. The mixture was left to boil for 30 minutes, at the end, rinses were carried out to eliminate the residues of the reagents and at the same time neutralize the mixture, subsequently, $200 \mathrm{ml}$ of $1.25 \%$ sodium hydroxide was added to the sample and it was allowed to boil for another 30 minutes, at the end, fiberglass rinses were performed until neutrality was reached. Subsequently, the fiberglass with the sample was placed in the capsule and they were introduced into the oven, it was left to dry for 12 hours to ensure that the sample was perfectly dry. After drying, the capsule was weighed with the glass fiber and the sample. By difference in weight, the percentage of fiber contained in each of the samples was determined.

\section{Total carbohydrates}

Determination of total carbohydrates was carried out by difference of the protein, fiber, fat, moisture and ash content and was reported in percentage.

\section{Metabolizable energy}

Energy contained in each of the samples was measured by the sum of the calories contained in carbohydrates, fat and protein, calculated using the Atwater system, reported by Acheson et al. (1980) Energy was expressed in Kcal.

\section{Extraction of bioactive compounds}

$1 \mathrm{~g}$ of raw beans was macerated with $10 \mathrm{ml}$ of $80 \%$ methanol and centrifuged at $2560 \mathrm{RCF}$ for 10 minutes at $4{ }^{\circ} \mathrm{C}$, then the aliquot was extracted to measure the following four parameters. 


\section{Antioxidant capacity}

For the determination of the antioxidant activity, the DPPH method described by Brand-Williams et al. (1996) was used, for which $500 \mu \mathrm{l}$ of each sample was taken and $2.5 \mathrm{ml}$ of DPPH $0.1 \mathrm{mM}$ prepared in $80 \%$ methanol was added to each one. All the reactions were carried out in one hour and at room temperature and in the absence of light; after the time the absorbance was measured at $517 \mathrm{~nm}$. Antioxidant activity is expressed as percentage of inhibition corresponding to the amount of DPPH radical neutralized by the extract at a certain concentration according to the following equation.

$$
\% \mathrm{I}=\frac{\mathrm{A}-\mathrm{A}_{1}}{\mathrm{~A}} * 100
$$

Where: $\mathrm{A}$ is the absorbance of the blank, $\mathrm{A}_{1}$ is the absorbance of the sample and $\% \mathrm{I}$ is the percentage of inhibition

\section{Total phenols}

The total phenols were determined by colorimetry against a gallic acid standard curve using the FolinCiocalteau method (Peyrat-Maillard et al., 2000); $250 \mu \mathrm{l}$ of sample added with $750 \mu \mathrm{l}$ of sodium carbonate 2 $\%$; subsequently, $250 \mu \mathrm{l}$ of reagent Folin-Ciocalteau $50 \%$ were added and filled to the mark with distilled water to make up the volume of $2.625 \mathrm{ml}$, finally, it was vortexed and incubated at room temperature for $60 \mathrm{~min}$; absorbance was measured at $725 \mathrm{~nm}$. Results were expressed in milligrams of gallic acid per gram $\left(\mathrm{mg} \mathrm{GA} \mathrm{g}^{-1}\right)$.

\section{Flavonoids}

Flavonoid analysis was performed following the method of Zhishen et al. (1999), $250 \mu \mathrm{l}$ of the sample was taken and $75 \mu \mathrm{l}$ of sodium nitrite $5 \%$ was added, it was vortexed, and the reaction was allowed to settle. for 5 minutes, once the time had elapsed, $150 \mu \mathrm{L}$ of $10 \%$ aluminum chloride were added together with $500 \mu \mathrm{L}$ of sodium hydroxide, finally, it was added with distilled water to make a volume of $3 \mathrm{ml}$. The samples were incubated for 45 minutes and then absorbance at $510 \mathrm{~nm}$ was measured; flavonoids were quantified based on a standard catechin curve and the results were expressed in $\mathrm{mg}$ of catechin per gram of dry weight $\left(\mathrm{MgCE} \cdot \mathrm{g}^{-1}\right)$.

\section{Monomeric anthocyanins}

To determine the content of monomeric anthocyanins, the differential method by $\mathrm{pH}$ described by Wrolstad (1976) was used. The reaction was divided in two phases.

The first consisted of taking $0.5 \mathrm{ml}$ of sample and adding $2 \mathrm{ml}$ of $0.25 \mathrm{M}$ potassium chloride adjusted to a $\mathrm{pH}$ of 1.0, then it was vortexed and the absorbance was measured at $460 \mathrm{~nm}$. For the second phase, $0.5 \mathrm{ml}$ of sample was taken and $2 \mathrm{ml}$ of $0.4 \mathrm{M}$ sodium acetate adjusted to a $\mathrm{pH}$ of 4.5 were added, and the same process was carried out as in phase one, with the difference that it was measured at a wavelength of $710 \mathrm{~nm}$. The monomeric anthocyanin content was calculated using the following formula:

$$
\frac{(\mathrm{A}-\mathrm{B}) *(449.2) *(0.2) *(1000)}{26900}
$$

Where $A-B$ is the difference between absorbances between phase 1 and phase 2, 449.2 is the molecular weight of cynadine-3-glucoside, 0.2 the dilution factor, 1000 is a constant and 26900 is the coefficient of molecular extinction of cynadine-3-glucoside.

The results were reported as $\mathrm{mg}$ of cynadin-3 glucoside per gram of sample ( $\left.\mathrm{mg} \mathrm{C} 3 \mathrm{G} \mathrm{g}^{-1}\right)$.

Phytic acid

For the determination of phytic acid, the method proposed by McKie and McCleary (2016) was used, for which the phosphorous total was obtained by the ammonium metavanadate method in an absorption range of $430 \mathrm{~nm}$ against a calibration curve of potassium phosphate. Once the results were obtained, the following formula was applied: 


$$
\text { Phytic Acid }=\frac{\text { Total phosphorous }}{0.282}
$$

Where 0.282 is a conversion factor from total phosphorous to phytic acid. Results were expressed in grams of phytic acid per each $100 \mathrm{~g}$ of dry weight of sample.

\section{Statistical analysis}

A Pearson's correlation analysis, as well as a cluster analysis of $\mathrm{K}$ means and a principal component analysis using the SPSS statistical package (SPSS, 2011).

\section{Results and Discussion}

\section{Physicochemical properties}

The selected bean varieties showed a large diversity size, color and probably due to the differences in geographical origin (Table 1). Mean protein content was $23.16 \%$, which is over the one reported by the U.S. Department of Agriculture (21-22\%) and with $11.61 \%$ of the varieties evaluated over the range (15-26.35\%) found for Mexican varieties of common beans (Chávez-Mendoza and Sánchez, 2017; USDA, 2018). In addition, very similar data were recorded for raw bean flour, to those reported in previous works for the variables of metabolizable energy, fat and carbohydrates, while for the fiber values the range found $(1.22-7.82 \%)$ is very much below the general fiber average for bean varieties worldwide (Campos-Vega et al., 2009; SuárezMartínez et al., 2016).

Table 1. Mean value of bioactive compounds and physicochemical properties of 155 bean genotypes

\begin{tabular}{|c|c|c|c|c|c|}
\hline Variable & Mean & Max. & Min. & SD & CV \\
\hline Fat (\%) & 1.38 & 2.97 & 0.41 & 0.52 & 0.38 \\
\hline Fiber (\%) & 3.31 & 7.82 & 1.22 & 1.18 & 0.36 \\
\hline Carbohydrates (\%) & 57.49 & 67.70 & 43.95 & 4.07 & 0.07 \\
\hline Protein (\%) & 23.16 & 29.79 & 17.48 & 2.81 & 0.12 \\
\hline Metabolizable energy (Kcal) & 335.05 & 355.15 & 306.10 & 10.07 & 0.03 \\
\hline Antioxidant capacity (\%) & 64.02 & 96.76 & 0.54 & 29.16 & 0.46 \\
\hline Phenols (mgGA/g) & 0.77 & 2.50 & 0.06 & 0.45 & 0.58 \\
\hline Flavonoids (mgCE/g) & 1.60 & 8.83 & 0.20 & 1.33 & 0.83 \\
\hline Anthocyanins (mgC3g/g) & 1.25 & 2.58 & 0.21 & 0.55 & 0.44 \\
\hline Phytic acid (mg/g) & 0.51 & 1.45 & 0.05 & 0.21 & 0.41 \\
\hline
\end{tabular}

\section{Bioactive compounds}

Regarding the bioactive compounds (Table 1), the antioxidant capacity range varied from 0.54 to $96.76 \%$ with a mean value of $64.02 \%$ exceeding $8.23 \%$ to the reported by Boateng et al. (2008), who found a mean value of $55.97 \%$ in varieties of red, black and pinto from Alabama, US. In turn, Garretson et al. (2018), reported a maximum value of $94.3 \%$ for purple beans of 'Koronis' variety; those studies show that our varieties are found within the range described for antioxidant capacity worldwide. However, it may be observed that, 62 $\%$ of varieties exceeded the higher value found by Chávez-Mendoza and Sánchez (2017) for Mexican varieties, which found a 'Flor de Junio' variety with an inhibition percentage of $29 \%$.

In respect of phenols content, results were between 0.06 y $2.5 \mathrm{mgGA} \cdot \mathrm{g}^{-1}$, which are found below the maximum values published by Garretson et al. (2018), Akond et al. (2011 $)$ and Gan et al. (2017); however, 8 
varieties registered values above the range for Mexican varieties (0.9-2.11 mgGA.g $\left.{ }^{-1}\right)$ reported by EspinozaAlonso et al. (2006). On the other hand, the range obtained for flavonoid content $\left(0.20-8.83 \mathrm{mgCE} . \mathrm{g}^{-1}\right)$ is found within the information reported by several researchers (Gan et al., 2017; Garretson et al., 2018). While for the anthocyanin and phytic acid parameters, maximum values were registered above those reported by Akond et al. $\left(2011_{1,2}\right)$ varieties from Colombia, US, Brazil and India. Regarding the previous results in Mexican varieties, anthocyanin exceeded the range from $0.01-1.85 \mathrm{mgC} 3 \mathrm{~g} . \mathrm{g}^{-1}$ published by Espinoza-Alonso et al. (2006) for 62 varieties of common bean. On the contrary, the content of phytic acid obtained an average of $1.45 \mathrm{mg} \cdot \mathrm{g}^{-1}$, which places it $0.08 \mathrm{mg} \cdot \mathrm{g}^{-1}$ below the average published by Iniestra-González et al. (2005) in 16 bean varieties of different seed coat colors.

\section{Correlation analysis}

In Pearson's correlation analysis, protein and fiber content parameters showed a negative correlation with carbohydrate content and with metabolizable energy (Table 2), which could be explained by the carbohydrate calculation method, which in turn is the parameter that most contributes to the calculation of metabolizable energy. A positive correlation was also found between said parameters with antioxidant capacity, while for bioactive compounds a high correlation was found between the content of phenols with flavonoids and anthocyanins, in addition to both being correlated with antioxidant capacity. In the case of beans, this results from the fact that antioxidant activity is related to the phenolic compound content they possess (Huber et al., 2016; Gan et al., 2017; García-Díaz et al., 2018). Finally, phytic acid showed a negative correlation with carbohydrates.

Table 2. Pearson correlation analysis with bean varieties grown in Mexico

\begin{tabular}{|c|c|c|c|c|c|c|c|c|c|c|}
\hline & Fat & Fiber & Carbohydrates & Protein & $\begin{array}{c}\text { Metabolizable } \\
\text { energy }\end{array}$ & $\begin{array}{c}\text { Antioxidant } \\
\text { capacity }\end{array}$ & Phenols & Flavonoids & Anthocyanins & $\begin{array}{c}\text { Phytic } \\
\text { acid }\end{array}$ \\
\hline \multirow{2}{*}{ Fat } & 1 & .063 & -.056 & -.123 & .099 & -.012 & -.080 & .021 & .024 & .047 \\
\hline & & .438 & .492 & .127 & .219 & .880 & .325 & .795 & .765 & .560 \\
\hline \multirow{2}{*}{ Fiber } & .063 & 1 & $-.476^{* *}$ & .086 & $-.503^{* *}$ & $-.303^{* *}$ & .115 & -.087 & -.010 & -.012 \\
\hline & .438 & & .000 & .288 & .000 & .000 & .153 & .281 & .899 & .882 \\
\hline \multirow{2}{*}{ Carbohydrates } & -.056 & $-.476^{*}$ & 1 & $-.542^{* *}$ & $.864^{* *}$ & $.307^{* *}$ & -.057 & $.207^{* 4}$ & -.061 & $176^{*}$ \\
\hline & .492 & .000 & & .000 & .000 & .000 & .480 & .010 & .451 & .028 \\
\hline \multirow{2}{*}{ Protein } & -.123 & .086 & $-.542^{* *}$ & 1 & -.094 & -.066 & -.030 & -.123 & .078 & .152 \\
\hline & .127 & .288 & .000 & & .247 & .412 & .710 & .128 & .332 & .059 \\
\hline \multirow{2}{*}{$\begin{array}{c}\text { Metabolizable } \\
\text { energy }\end{array}$} & .099 & $-.503^{*+}$ & $.864^{* *}$ & -.094 & 1 & $.325^{* 1}$ & -.105 & $.180^{\circ}$ & -.021 & -.111 \\
\hline & .219 & .000 & .000 & .247 & & .000 & .195 & .025 & .792 & .171 \\
\hline \multirow{2}{*}{$\begin{array}{c}\text { Antioxidant } \\
\text { capacity }\end{array}$} & -.012 & $-.303^{*+}$ & $.307^{* *}$ & -.066 & $.325^{* *}$ & 1 & .021 & $.185^{*}$ & $.163^{*}$ & .043 \\
\hline & .880 & .000 & .000 & .412 & .000 & & .791 & .022 & .043 & .599 \\
\hline \multirow{2}{*}{ Phenols } & -.080 & .115 & -.057 & -.030 & -.105 & .021 & 1 & $.354^{* *}$ & $.221^{*}$ & .008 \\
\hline & .325 & .153 & .480 & .710 & .195 & .791 & & .000 & .006 & .917 \\
\hline \multirow{2}{*}{ Flavonoids } & .021 & -.087 & $.207^{* *}$ & -.123 & $.180^{\circ}$ & $.185^{*}$ & $.354^{* 4}$ & 1 & .121 & .145 \\
\hline & .795 & .281 & .010 & .128 & .025 & .022 & .000 & & .132 & .072 \\
\hline \multirow{2}{*}{ Anthocyanins } & .024 & -.010 & -.061 & .078 & -.021 & $.163^{*}$ & $.221^{* *}$ & .121 & 1 & -.147 \\
\hline & .765 & .899 & .451 & .332 & .792 & .043 & .006 & .132 & & .069 \\
\hline \multirow{2}{*}{ Phytic acid } & .047 & -.012 & $176^{*}$ & .152 & -.111 & .043 & .008 & .145 & -.147 & 1 \\
\hline & .560 & .882 & .028 & .059 & .171 & .599 & .917 & .072 & .069 & \\
\hline
\end{tabular}

**. The correlation is significant at the 0.01 level (bilateral).

*. The correlation is significant at the 0.05 level (bilateral).

\section{Cluster analysis}

The cluster analysis (Table 3) was performed based on the physicochemical properties and the content of bioactive compounds, obtaining as a result five groupings based on their similarities, from which clusters 2 and 3 were selected because the varieties that the conglomerates presented the highest values for protein, fibre and anthocyanins (cluster 2) as well as the highest phenol and flavonoid values (cluster 3). Phytic acid content was not taken into account when selecting the outstanding groups, because its capacity as a beneficial or antinutritional compound does not depend on the content or the source that comes from Rather, it depends 
on the diet followed by the consumer, since in a diet based on grains and cereals with a low mineral protein intake, phytic acid can act negatively, on the contrary, in a balanced diet with micronutrients availability, the phytic acid expresses its value as a bioactive compound (Díaz-Batalla et al., 2006).

Table 3. Centre of final clusters for 155 bean varieties

\begin{tabular}{|c|c|c|c|c|c|}
\hline & \multicolumn{5}{|c|}{ Cluster } \\
\cline { 2 - 6 } & 1 & 2 & 3 & 4 & 5 \\
\hline Number of varieties & 45 & 10 & 4 & 56 & 40 \\
\hline Protein (\%) & 20.16 & 28.13 & 19.89 & 23.18 & 25.25 \\
\hline Phenols (mgGA/g) & 0.90 & 0.79 & 1.63 & 0.81 & 0.79 \\
\hline Flavonoids (mgCE/g) & 1.44 & 1.11 & 5.78 & 1.36 & 1.63 \\
\hline Anthocyanins (mgC3g/g) & 1.17 & 1.51 & 1.35 & 1.20 & 1.15 \\
\hline Phytic acid (mg/g) & 0.49 & 0.53 & 0.59 & 0.51 & 0.58 \\
\hline Fat (\%) & 1.43 & 1.56 & 1.63 & 1.31 & 1.26 \\
\hline Fiber (\%) & 3.51 & 4.55 & 3.33 & 3.27 & 3.67 \\
\hline Carbohydrates (\%) & 62.36 & 49.26 & 59.01 & 58.26 & 54.90 \\
\hline
\end{tabular}

We obtained a total of 14 outstanding varieties (Table 4), where 4 varieties stood out in terms of their content of phenols and flavonoids, a second group composed of 10 varieties with high levels of protein and anthocyanins. Moreover, this group showed a low percentage of carbohydrates and a high content of fibre and fat, which makes these varieties future foods with a low glycaemic index (American Diabetes Association, 2015). A great diversity can be observed within the outstanding group, where there are varieties from different regions of the country and different shapes, sizes and colours of the bean grain. The outstanding varieties, according to the cluster analysis, showed great diversity, 'FIRA (2016)', indicate that beans are located in three large consumption groups: highly preferred ('Azufrado', 'Mayocoba', 'Negro Jamapa', 'Peruano', 'Flor de Mayo' and 'Flor de Junio'), preferred ('Garbancillo', 'Manzano', 'Negro' and 'Pinto Americano') and non-preferred ('Alubia', 'Bayo', 'Negro Zacatecas', 'Ojo de Cabra' and 'Pinto Mexicano'). Therefore, within the results obtained, there is at least one variety of the most consumed beans within the national territory. Also, five varieties of black and pinto beans were obtained, which together contribute more than $60 \%$ of the national production (Lara-Flores, 2015; FIRA, 2016).

\section{Main components analysis}

On the other hand, the principal component analysis had information on 6 variables that included bioactive compounds, protein content and carbohydrate content (Table 5). The first three components explained $74.75 \%$ of the total variation: first component $31.09 \%$, second component $24.48 \%$ and third component $19.18 \%$. In the first component, the most significant variables were the content carbohydrate, phenols and flavonoids. In addition, there was a contrast in the protein content with carbohydrates. In the second component, there was a contrast between the bioactive compounds (phenols, flavonoids, anthocyanins and phytic acid) and the protein content with the carbohydrate content. While in the third component, he contrasted the concentration of phytic acid with that of anthocyanins. 
Palacio-Márquez A et al. (2021). Not Bot Horti Agrobo 49(1):12123

Table 4. Outstanding bean varieties based on the cluster analysis

\begin{tabular}{|c|c|c|c|c|c|c|c|}
\hline No & Variety & Place & Protein & Phenols & Flavonoids & Anthocyanins & Photo \\
\hline 43 & $\begin{array}{c}\text { 'Pelón } \\
\text { Obscuro' }\end{array}$ & Teapa, Tabasco & 26.75 & 0.5682 & 1.3183 & 0.8617 & \\
\hline 54 & $\begin{array}{c}\text { 'Frijol } \\
\text { Mejenives' }\end{array}$ & Dzutoh, Yucatán & 29.08 & 0.4476 & 0.7689 & 0.9268 & \\
\hline 57 & 'X-Pelón' & Dzutoh, Yucatán & 29.37 & 2.4982 & 1.6795 & 2.5149 & \\
\hline 63 & 'Pelón Rojo' & Teapa, Tabasco & 28.72 & 1.1054 & 1.7473 & 1.3593 & \\
\hline 67 & $\begin{array}{l}\text { 'Higuera } \\
\text { azufrado' }\end{array}$ & Culiacán, Sinaloa & 28.86 & 0.3470 & 0.7652 & 1.1472 & \\
\hline 74 & 'Alubia' & $\begin{array}{c}\text { Guadalajara, } \\
\text { Jalisco }\end{array}$ & 25.98 & 0.3050 & 0.9533 & 0.8260 & \\
\hline 82 & $\begin{array}{l}\text { 'Ejotero } \\
\text { Silvestre' }\end{array}$ & $\begin{array}{l}\text { San Juanito, } \\
\text { Chihuahua }\end{array}$ & 29.79 & 0.2713 & 1.3748 & 1.6482 & \\
\hline 84 & 'Negro guaca' & $\begin{array}{l}\text { Tuxtepec, } \\
\text { Oaxaca }\end{array}$ & 28.13 & 1.0155 & 1.3371 & 1.8068 & \\
\hline 87 & 'Negro' & $\begin{array}{l}\text { Tuxtepec, } \\
\text { Oaxaca }\end{array}$ & 27.44 & 0.7868 & 0.6447 & 1.8480 & \\
\hline 98 & $\begin{array}{l}\text { 'Sangre de } \\
\text { Toro' }\end{array}$ & $\begin{array}{c}\text { Tlayacacan, } \\
\text { Morelos }\end{array}$ & 18.65 & 0.9497 & 3.1584 & 2.4002 & \\
\hline 100 & 'Peruano' & Cuautla, Morelos & 27.19 & 0.6062 & 0.5507 & 2.1475 & \\
\hline 114 & $\begin{array}{l}\text { 'Frijolón } \\
\text { Amarillo' }\end{array}$ & $\begin{array}{c}\text { Nochixtlán, } \\
\text { Oaxaca }\end{array}$ & 19.52 & 2.3486 & 8.8254 & 0.7125 & \\
\hline 133 & $\begin{array}{l}\text { 'Frijolón } \\
\text { Negro' }\end{array}$ & Ocotlán, Oaxaca & 21.00 & 1.2383 & 5.5441 & 0.9129 & \\
\hline 138 & 'Frijolón 1' & Centro, Oaxaca & 20.38 & 1.9739 & 5.5817 & 1.3649 & \\
\hline
\end{tabular}


Palacio-Márquez A et al. (2021). Not Bot Horti Agrobo 49(1):12123

Table 5. Principal components of six quality variables observed in 155 bean varieties grown in Mexico

\begin{tabular}{|c|c|c|c|}
\hline \multirow{2}{*}{ Variable } & \multicolumn{3}{|c|}{ Principal components (PC) } \\
\cline { 2 - 4 } & 1 & 2 & 3 \\
\hline Protein $(\%)$ & -.927 & .133 & -.041 \\
\hline Phenols $(\mathrm{mgGA} / \mathrm{g})$ & .210 & .768 & -.009 \\
\hline Flavonoids $(\mathrm{mgCE} / \mathrm{g})$ & .220 & .718 & .333 \\
\hline Anthocyanins $(\mathrm{mgC3g} / \mathrm{g})$ & -.064 & .555 &. .602 \\
\hline Phytic acid $(\mathrm{mg} / \mathrm{g})$ & -.242 & .140 & .055 \\
\hline Carbohydrates $(\%)$ & .922 & -.138 & .055 \\
\hline
\end{tabular}

The spatial distribution of varieties was made based on the first 2 components (Figure 1), it can be observed in quadrant I (upper-right) a clustering trend based on the high concentrations of the bioactive compounds evaluated, in turn quadrant IV (upper-left) groups varieties with high concentrations of bioactive compounds and also adds varieties with high levels of protein. Finally, in quadrants II and III (Lower-right and lower-left) those varieties were found with a high content of carbohydrates, but which did not stand out in the levels of the other variables evaluated.

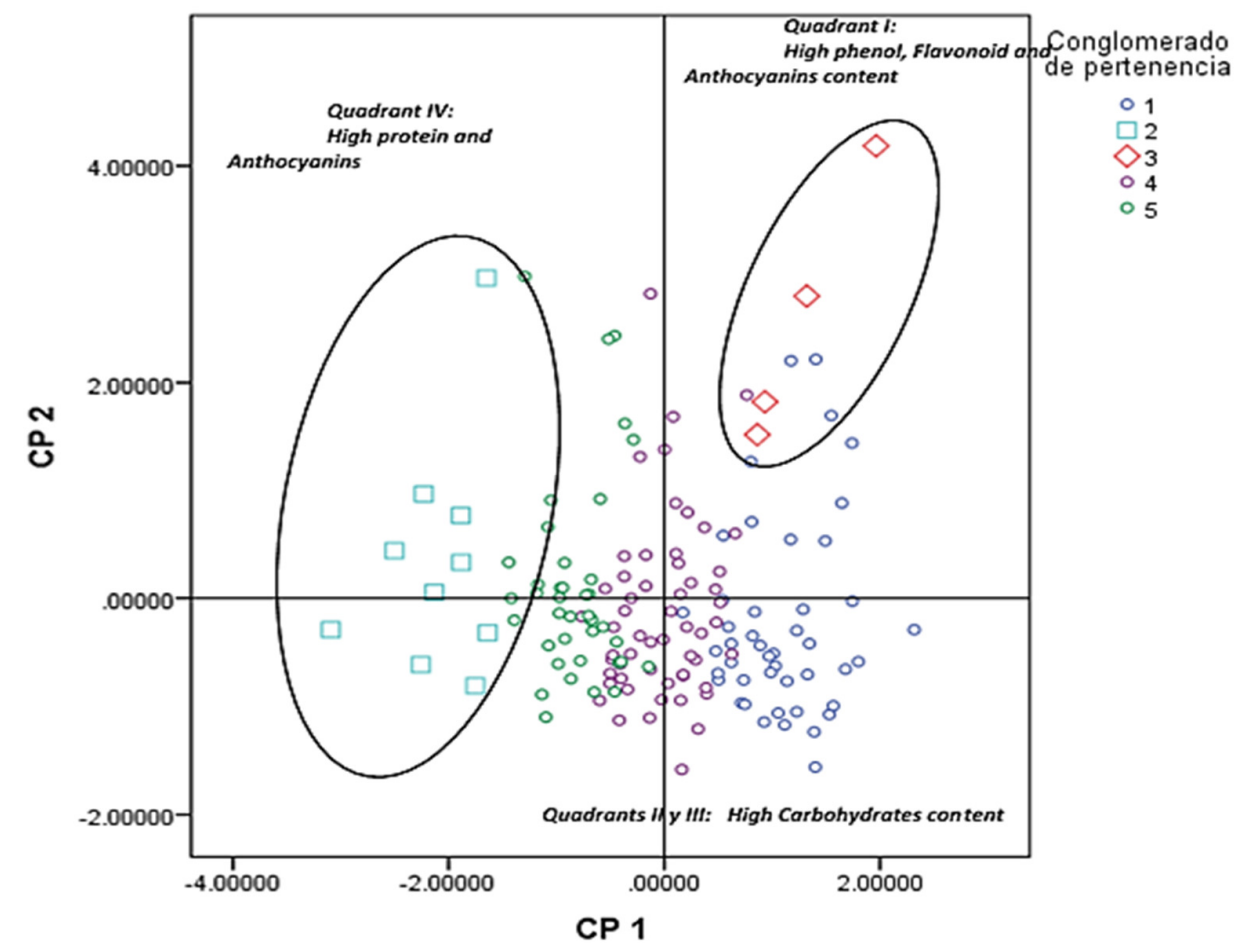

Figure 1. Spatial distribution of 155 bean varieties based on their first two components, grouped according to the cluster analysis 


\section{Conclusions}

Fourteen outstanding varieties were obtained, based on the variables evaluated, where 4 stood out for their high levels of phenols and flavonoids; On the other hand, 10 more varieties stood out for a high level of protein, in addition to acceptable levels of anthocyanins, phytic acid and a low content of carbohydrates. Varieties such as 'Frijolón 1', 'Frijolón Amarillo', 'Frijolón negro' and 'Sangre de toro' were remarkable due to their high content of bioactive compounds, so it is recommended to incorporate these varieties to a biofortification program to improve the nutritional quality of beans. The other 10 remaining varieties, due to their high protein content, are recommended to be used as an alternative of vegetal protein with a good glycemic index. The diversity of beans obtained in the outstanding varieties generates options for biofortification programs based on the consumption of each variety or its place of origin.

\section{Authors' Contributions}

Conceptualization: ES; Methodology: APM, DOB; Validation: JJC, OAHR; Formal analysis: APM, JJC; Investigation: APM, DOB, OAHR; Data curation: ES, PPR; Funding acquisition: ES; Proyect administration: ES; Writing: APM, ES; Review and editing: APM, ES; All authors read and approved the final manuscript.

\section{Acknowledgements}

Alejandro Palacio Márquez acknowledgements financial support given by Plant Physiology and Nutrition Laboratory of the Food and Development Research Center (CIAD Delicias) And the National Council of Science and Technology (CONACyT - Mexico) for the support provided by means of the Convocatoria Atención a Problemas Nacionales: Project \#1529 "Biofortification of basic agricultural crops representing the key to combat malnutrition and ensure food security in Mexico"

\section{Conflict of Interests}

The authors declare that there are no conflicts of interest related to this article.

\section{References}

Acheson KJ, Campbell IT, Edholm OG, Miller DS, Stock MJ (1980). The measurement of food and energy intake in man-an evaluation of some techniques. American Journal of Clinical Nutrition 33(5):1147-1154. https://doi.org/10.1093/ajcn/33.5.1147.

Akond AGM, Heath Crawford JB, Talukder ZI, Hossain K (2011). Minerals (Zn, Fe, Ca and Mg) and antinutrient (phytic acid) constituents in common bean. American Journal of Food Technology 6(3):235. https://doi.org/10.3923/ajft.2011.235.243

Akond AGM, Khandaker L, Berthold J, Gates L, Peters K, Delong H, Hossain K (2011). Anthocyanin, total polyphenols and antioxidant activity of common bean. American Journal of Food Technology 6(5):385-394. https://doi.org/10.3923/ajft.2011.385.394

American Diabetes Association (2015). Índice glucémico y diabetes. Retrieved 2018 September 28 from http://www.diabetes.org 
AOAC (2000). Association of official analytical chemist. In: AOAC International (Ed). Official Methods of Analysis $\left(17^{\text {th }}\right)$. Guithersbur, MD, EE. UU.

Boateng J, Verghese M, Walker LT, Ogutu S (2008). Effect of processing on antioxidant contents in selected dry beans (Phaseolus spp. L.). LWT-Food Science and Technology 41(9):1541-1547. https://doi.org/10.1016/j.lwt.2007.11.025

Brand-Williams W, Cuvelier ME, Berset, CLWT (1995). Use of a free radical method to evaluate antioxidant activity. LWT-Food Science and Technology 28(1):25-30. https://doi.org/10.1016/S0023-6438(95)80008-5

Câmara CR, Urrea CA, Schlegel V (2013). Pinto beans (Phaseolus vulgaris L.) as a functional food: Implications on human health. Agriculture 3(1):90-111. https://doi.org/10.3390/agriculture3010090

Campos-Vega R, Reynoso-Camacho R, Pedraza-Aboytes G, Acosta-Gallegos JA, Guzman-Maldonado SH, ParedesLopez O, Loarca-Piña G (2009). Chemical composition and in vitro polysaccharide fermentation of different beans (Phaseolus vulgaris L.). Journal of Food Science 74(7):59-65. https://doi.org/10.1111/j.17503841.2009.01292.x

Chávez-Mendoza C, Sánchez E (2017). Bioactive compounds from Mexican varieties of the common bean (Phaseolus vulgaris): Implications for health. Molecules 22(8):1360. https://doi.org/10.3390/molecules22081360

Díaz-Batalla L, Widholm JM, Fahey GC, Castaño-Tostado E, Paredes-López O (2006). Chemical components with health implications in wild and cultivated Mexican common bean seeds (Phaseolus vulgaris L.). Journal of Agricultural and Food Chemistry 54(6):2045-2052. https://doi.org/10.1021/jf0517061

Espinosa-Alonso LG, Lygin A, Widholm JM, Valverde ME, Paredes-Lopez O (2006). Polyphenols in wild and weedy Mexican common beans (Phaseolus vulgaris L.). Journal of Agricultural and Food Chemistry 54(12):4436-4444. https://doi.org/10.1021/jf060185e

FIRA (2016). Panorama agroalimentario: Frijol. Fideicomisos Instituidos en Relación con la Agricultura pp 1-37.

Gan RY, Wang MF, Lui WY, Wu K, Dai SH, Sui ZQ, Corke H (2017). Diversity in antioxidant capacity, phenolic contents, and flavonoid contents of 42 edible beans from China. Cereal Chemistry 94(2):291-297. https://doi.org/10.1094/CCHEM-03-16-0061-R

García-Díaz YD, Aquino-Bolaños EN, Chávez-Servia JL, Vera-Guzmán AM, Carrillo-Rodríguez JC (2018). Bioactive compounds and antioxidant activity in the common bean are influenced by cropping season and genotype. Chilean Journal of Agricultural Research 78(2):255-265. http://doi.org/10.4067/S0718-58392018000200255

Garretson L, Tyl C, Marti A (2018). Effect of processing on antioxidant activity, total phenols, and total flavonoids of pigmented Heirloom beans. Journal of Food Quality 7836745:1-6. https://doi.org/10.1155/2018/7836745

Gutierrez J (2012). Calidad de vida, alimentos y salud humana: fundamentos científicos [Quality of life, food and human health: scientific foundations]. In: de Santos D (Ed). $1^{\text {st }}$ Ed, Madrid, pp 64-66.

Huber K, Brigide P, Bretas EB, Canniatti-Brazaca SG (2016). Phenolic acid, flavonoids and antioxidant activity of common brown beans (Phaseolus vulgaris L.) before and after cooking. Journal of Nutrition and Food Sciencies 6:1-7. https://doi.org/10.4172/2155-9600.1000551

Iniestra-González JJ, Ibarra-Pérez FJ, Gallegos-Infante JA, Rocha-Guzmán NE, González-Laredo RF (2005). Factores antinutricios y actividad antioxidante en variedades mejoradas de frijol común (Phaseolus vulgaris) [Antinutritional factors and antioxidant activity in improved varieties of common bean (Phaseolus vulgaris)]. Agrociencia 39(6).

Korus J, Gumul D, Czechowska K (2007) Effect of extrusion on the phenolic composition and antioxidant activity of dry beans of Phaseolus vulgaris L. Food Technology and Biotechnology 45(2):139-146.

Lara-Flores M (2015). El cultivo del frijol en México [The cultivation of beans in Mexico]. Revista Digital Universitaria UNAM 16(2):9.

McKie VA, McCleary BV (2016). A novel and rapid colorimetric method for measuring total phosphorus and phytic acid in foods and animal feeds. Journal of AOAC International 99(3):738-743. https://doi.org/10.5740/jaoacint.16-0029

Mederos Y (2006). Indicadores de la calidad en el grano de frijol (Phaseolus vulgaris L.). [Quality indicators in bean (Phaseolus vulgaris L.)]. Cultivos Tropicales 27:55-63.

Messina V (2014). Nutritional and health benefits of dried beans. The American Journal of Clinical Nutrition 100(1):437S-442S. https://doi.org/10.3945/ajcn.113.071472

Peyrat-Maillard MN, Bonnely S, Berset C (2000). Determination of the antioxidant activity of phenolic compounds by coulometric detection. Talanta 51(4):709-716. https://doi.org/10.1016/S0039-9140(99)00331-8 
Sánchez-Chávez E, García-Bañuelos M, Sida-Arreola J, Muñoz-Márquez E (2013). Estrategia de Innovación para mejorar la calidad nutricional y calidad antioxidante en frijol a través del proceso de biofortificación con hierro y zinc [Innovation strategy to improve nutritional quality and antioxidant quality in beans through the biofortification process with iron and zinc]. Romero L (Ed). 1st ed. Granada, España, pp 120.

Sida-Arreola JP, Sánchez E, Ávila-Quezada GD, Acosta-Muñíz CH, Zamudio-Flores PB (2015). Biofortificación con micronutrientes en cultivos agrícolas y su impacto en la nutrición y salud humana [Biofortification with micronutrients in agricultural crops and their impact on nutrition and human health]. Tecnociencia Chihuahua $9(2): 67-74$.

Silva-Cristobal L, Osorio-Díaz P, Tovar J, Bello-Pérez LA (2010) Chemical composition, carbohydrate digestibility, and antioxidant capacity of cooked black bean, chickpea, and lentil Mexican varieties. CyTA-Journal of Food 8(1):714. https://doi.org/10.1080/19476330903119218

SPSS (2011). IBM SPSS statistics base 20. Chicago, IL: SPSS Inc.

Suárez-Martínez SE, Ferriz-Martínez RA, Campos-Vega R, Elton-Puente JE, de la Torre Carbot K, García-Gasca T (2016) Bean seeds: leading nutraceutical source for human health. CyTA-Journal of Food 14(1):131-137. http://dx.doi.org/10.1080/19476337.2015.1063548

Ulloa A, Ulloa P, Ramírez J, Ulloa B (2011). El frijol (Phaseolus vulgaris): su importancia nutricional y como fuente de fitoquímicos [The bean (Phaseolus vulgaris): its nutritional importance and as a source of phytochemicals]. Revista Fuente 3(8):5-9.

USDA (2018). Food Composition Databases Show Foods - Beans, pinto, mature seeds, raw (Includes foods for USDA's Food Distribution Program). Retrieved 2018 September 25 from: https://ndb.nal.usda.gov/ndb/foods/show/16042

Wrolstad RE (1976). Color and pigment analysis in fruit products. S Bulletin. 624 Agricultural Experiment Station, Oregon State University, Corvallis.

Xu B, Chang SK (2009). Total phenolic, phenolic acid, anthocyanin, flavan-3-ol, and flavonol profiles and antioxidant properties of pinto and black beans (Phaseolus vulgaris L.) as affected by thermal processing. Journal of Agricultural and Food Chemistry 57(11):4754-4764. https://doi.org/10.1021/jf900695s

Zhishen J, Mengcheng T, Jianming W (1999). The determination of flavonoid contents in mulberry and their scavenging effects on superoxide radicals. Food Chemistry 64(4):555-559. https://doi.org/10.1016/S03088146(98)00102-2

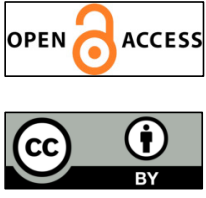

\footnotetext{
The journal offers free, immediate, and unrestricted access to peer-reviewed research and scholarly work. Users are allowed to read, download, copy, distribute, print, search, or link to the full texts of the articles, or use them for any other lawful purpose, without asking prior permission from the publisher or the author.

License - Articles published in Notulae Botanicae Horti Agrobotanici Cluj-Napoca are Open-Access, distributed under the terms and conditions of the Creative Commons Attribution (CC BY 4.0) License. (c) Articles by the authors; UASVM, Cluj-Napoca, Romania. The journal allows the author(s) to hold the copyright/to retain publishing rights without restriction.
} 